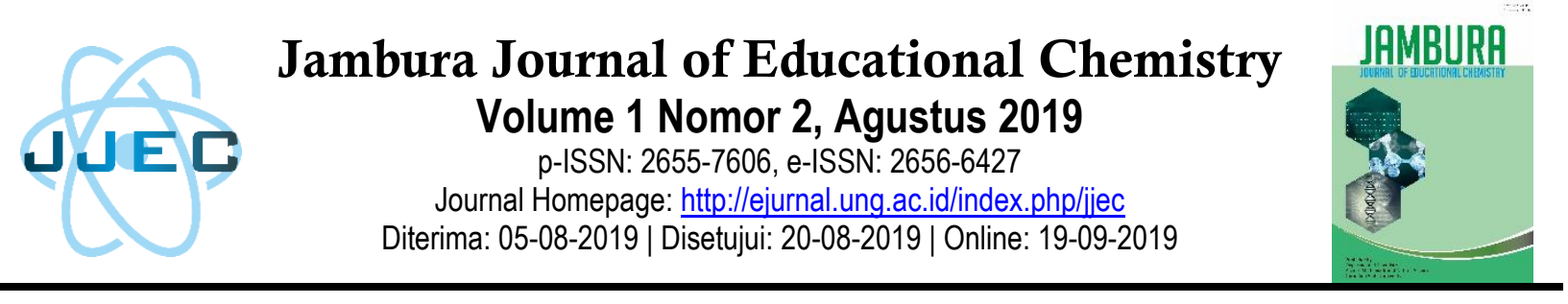

\title{
Implementasi Self-Efficacy dan Keterampilan Berpikir Kritis Siswa Pada Pembelajaran Kimia di Abad 21
}

\author{
Siti Nuraeni1, Tonih Feronika², dan Luki Yunita ${ }^{3}$ \\ 1,2,3Program Studi Pendidikan Kimia, Fakultas Ilmu Tarbiyah dan Keguruan, Universitas \\ Islam Negeri Syarif Hidayatullah Jakarta, Jl. Ir. H. Juanda No. 95, Ciputat 15412, Indonesia \\ e-mail: ${ }^{1}$ nuraenisiti298.sn@gmail.com
}

\begin{abstract}
Abstrak
Perkembangan Abad ke-21 memberikan perubahan total baik pada berbagai bidang, tak terlepas dunia pendidikan. Perubahan ini perlu diantisipasi dengan menguasai keterampilan abad 21 yaitu keterampilan 4C (Creativity and Innovation, Critival Thinking and Problem Solving, Communication, and Collaboration). Namun masih ditemukan sekolah yang belum menerapkan pembelajaran yang berkaitan dengan keempat keterampilan tersebut. Penelitian ini memfokuskan pada aspek critical thinking dalam pembelajaran kimia. Pengembangan berpikir kritis salah satunya dipengaruhi oleh selfefficacy atau keyakinan diri yang mampu meningkatkan kemampuan penyelesaian masalah (Hoffman \& Schraw, 2009). Penelitian ini bertujuan untuk mengetahui sejauhmana peran self-efficacy dalam kaitannya dengan berpikir kritis. Metode yang digunakan pada penelitian ini adalah metode korelasional. Dengan menggunakan teknik purposive sampling, sebanyak 63 siswa dari kelas XI MIPA di SMAN 2 Kab. Tangerang dipilih sebagai sampel. Data dikumpulkan dengan angket Physic Learning Self-Efficacy yang diadaptasi dari Suprapto dan Chang (2017) dan tes uraian keterampilan berpikir kritis yang diadaptasi dari Ennis (1985). Hasil memunjukkan bahwa self-efficacy memberikan sebuah hubungan yang positif dengan berpikir kritis pada pembelajaran kimia.
\end{abstract}

Kata kunci: Self-efficacy, keterampilan berpikir kritis, kimia

\section{PENDAHULUAN}

Perkembangan Abad ke-21 tidak terlepas dari hadirnya era revolusi industri 4.0 sebagai abad keterbukaan atau abad gobalisasi, artinya kehidupan manusia pada abad ke-21 mengalami perubahanperubahan yang fundamental yang berbeda dengan tata kehidupan dalam abad sebelumnya, revolusi industri keempat ditandai dengan kemajuan teknologi melalui rekayasa intelegensia dan Internet of Thing (IoT) sebagai sarana penghubung antara manusia dan mesin (Sukartono, 2019). Sedangkan dunia pendidikan sudah memasuki revolusi yang kelima yang ditandai dengan dimanfaatkannya sarana komputer dan internet dalam proses pembelajaran (Rusman, 2013). Sejalan dengan hal tersebut, tentunya manusia masa kini diharapkan mampu mengolah dan memproses informasi yang didapat dari media internet dengan akurat dan tepat. Dibutuhkan sebuah keterampilan khusus agar tidak terbawa pesatnya arus informasi. Dunia pendidikan juga memiliki peran untuk menghasilkan peserta didik agar tidak terjerumus ke dalam arus informasi yang salah agar kedepannya bisa menjadi sumber daya manusia yang berkualitas. Kegiatan pembelajaran di kelas perlu didesain dengan tepat agar dihasilkan peserta didik yang berkompeten.

P21 (Partnership for $21^{\text {st }}$ Century Learning) mengambangkan framework pembelajaran pada abad ke-21 yang menuntut peserta didik memiliki keterampilan 4C (Creativity and Innovation, Critival Thinking and Problem Solving, Communication, and Collaboration). Keterampilan 
tersebut sangat dibutuhkan mengingat peserta didik saat ini berada pada era modern yang dikendalikan oleh pesatnya arus informasi (Sutarno, Setiawan, Suhandi, Kaniawati, \& Hamdani, 2018). Sehingga peserta didik membutuhkan penguasaan pengolahan informasi yang berguna dengan baik.

Pendidikan saat ini lebih mengedepankan peserta didik aktif berpartisipasi dalam proses pembelajaran. Artinya, peran guru hanyalah sebagai mediator peserta didik dalam mendapatkan pengetahuan. Peserta didik dituntut untuk mampu mendapatkan pemahaman secara mandiri, hal ini bertujuan untuk mengasah keterampilan kognitif peserta didik. Dengan kata lain peserta didik perlu memiliki keterampilan kognitif tingkat tinggi (4C) seperti kemampuan pemecahan masalah, menganalisis masalah, berpikir kreatif dan mampu membuat keputusan dengan baik.

Berpikir kritis merupakan seperangkat praktik pengetahuan yang beragam yang melibatkan pertanyaan mendalam. De Bono (2007) mengatakan bahwa, pemikiran kritis adalah kemampuan untuk berpikir secara logis, reflektif, dan produktif yang fokus dalam menentukan apa yang harus dipercaya atau dilakukan yang kemudian diaplikasikan dalam menilai situasi untuk membuat pertimbangan dan keputusan yang baik. Seseorang yang memiliki kemampuan berpikir kritis akan mampu memilih dan menganalisis kebenaran suatu informasi, serta membuat keputusan dengan baik.

Ennis (1985) berpendapat bahwa critical thinking is a process, the goal of which is to make reasonable decisions about what to believe and what to do. Seseorang yang berpikir kritis adalah orang yang mampu dan memiliki kecenderungan untuk percaya dan bertindak sesuai dengan penalarannya. Sejalan dengan itu, Gurcay \& Ferah (2018); Mabruroh \& Suhandi (2017) mengatakan tujuan utama pendidikan sains adalah untuk mempersiapkan siswa memahami konsep dan meningkatkan keterampilan berpikir. Oleh karena itu, dalam proses pembelajaran di kelas keterampilan berpikir kritis sangatlah diperlukan untuk membantu siswa memiliki pola pikir tingkat tinggi. Seseorang yang memiliki kemampuan berpikir kritis akan mampu menemukan solusi alternatif untuk masalah yang dihadapinya. Untuk dapat memiliki kemampuan berpikir kritis diperlukan sebuah proses, peserta didik tidak secara serta merta memiliki kemampuan tersebut hanya dalam satu kali proses pembelajaran. Namun menurut Hohmann \& Grillo (2014) masih ditemukan peserta didik yang tidak menyadari bahwa berjuang untuk memahami dan mempertahankan konsep yang kompleks merupakan bagian normal dari proses pembelajaran, atau masih ditemukan peserta didik yang tidak memperdulikan proses atau hanya ingin mendapatkan pemahaman secara instan saja. Keterampilan berpikir kritis tidak akan menjadi kuat apabila tidak melalui sebuah proses sampai siswa mampu bertahan dalam kebingungan dan ketidakpastian untuk sampai kepada stabilnya keterampilan tersebut. Waktu yang dibutuhkan untuk memproses informasi yang sulit inilah yang dapat menjadi tantangan bagi banyak peserta didik.

Perkembangan kemampuan berpikir kritis dipengaruhi oleh berbagai hal, salah satunya faktor kepribadian. Termasuk adalah self-efficacy. Hoffman \& Schraw (2009) mengatakan bahwa selfefficacy dan kemampuan berpikir kritis memiliki keterkaitan. Self-efficacy didefinisikan sebagai kepercayaan seseorang tentang kemampuan diri sendiri untuk menghasilkan tingkat kinerja yang berpengaruh terhadap kejadian yang mempengaruhi kehidupan orang tersebut. Self-efficacy menentukan bagaimana orang merasa, berpikir, memotivasi diri, dan berperilaku (Bandura, 2010). Sejalan dengan hal tersebut, Santrock \& Santrock (2007) mengatakan, siswa dengan sel-efficacy yang tinggi memiliki kemungkinan yang lebih besar untuk mengerahkan upaya dan bertahan lebih lama dalam mengerjakan tugas dibanding siswa dengan selfefficacy rendah. Siswa yang memiliki rasa percaya diri yang tinggi akan lebih mampu mengembangkan pemikirannya ke arah pemikiran kritis sehingga dapat menyelesaikan tugas-tugas dengan baik (Cheung, 2015).

Berdasarkan penjelasan-penjelasan diatas, dapat dikatakan bahwa self-efficacy seseorang memberikan pengaruh terhadap kemampuan seseorang dalam menyelesaikan tugas atau tuntutan tertentu yang juga memerlukan keahlian dalam 
berpikir tingkat tinggi dalam hal ini kaitannya dengan berpikir kritis.

Menurut Bandura (1977), self-efficacy yang dimiliki peserta didik timbul dari 4 sumber yaitu pengalaman sukses dalem menyelesaikan tugas (performance accomplishment), pengalaman yang diperoleh dari melakukan sesuatu (vicarious experience), persuasi verbal (verbal persuasion), dan keadaan fisiologis (physicological states). Keempat sumber tersebut tidak muncul dengan sendirinya tapi melalui proses yang tentunya melibatkan ranah kognitif siswa.

Di sekolah, peserta didik perlu menganggap diri mereka sukses dalam pembelajaran sains. Pajares (2002) mengatakan bahwa dalam konteks IPA, self-efficacy merupakan ranah untuk membagun tugas khusus yaitu keyakinan diri seseorang yang berviariasi pada setiap bidang ilmu seperti fisika, kimia, dan biologi. Bahkan untuk ilmu kimia, keyakinan terhadap kemampuan seseorang dapat berbeda-beda di setiap topik atau materi. Self-efficacy yang baik akan menghasilkan keterampilan berpikir kritis yang baik.

Ilmu kimia dan berpikir kritis merupakan dua hal yang tidak dapat dipisahkan, ilmu kimia mengandung konsep yang bersifat kompleks. Untuk dapat memahaminya diperlukan sebuah penalaran yang mendalam. Seehingga dapat dikatakan bahwa materi kimia merupakan salah satu mata pelajaran yang dapat meningkatkan berpikir kritis peserta didik. Self-efficacy yang tinggi terhadap konsep kimia tentunya akan mempengaruhi berpikir kritis peserta didik pada konsep kimia.

Tujuan penelitian ini adalah untuk mengetahui sejauh mana nilai self-efficacy memengaruhi nilai keterampilan berpikir kritis siswa pada pembelajaran kimia, sehingga dapat diharapkan penelitian ini dapat dijadikan salah satu salah satu sumber informasi terkait self-efficacy atau sejauh mana tingkat kepercayaan diri siswa terhadap kemampuannya dengan keterampilan berpikir kritis siswa.

\section{METODE PENELITIAN Jenis Penelitian}

Penelitian ini menggunakan metode deskriptif kuantitatif. Adapun jenis penelitian yang digunakan dalam penelitian ini adalah penelitian korelasional untuk mengetahui sejauh mana hubungan antara variabel-variabel berdasarkan koefisien korelasi.

\section{Waktu dan Tempat Penelitian}

Penelitian ini dilakukan pada semester ganjil tahun pelajaran 2018/2019 yaitu bulan Desember 2018 di MAN 1 Tangerang Selatan dan SMA N 2 Kab.Tangerang.

\section{Target/Subjek Penelitian}

Populasi pada penelitian ini adalah seluruh siswa SMAN 2 Kab. Tangerang tahun pelajaran 2018/2019. Sedangkan sampel yang diambil oleh peneliti ialah siswa kelas XI MIPA MAN 1 Tangerang Selatan dan SMAN 2 Kab. Tangerang dengan total 117 orang. Pengambilan sampel dalam penelitian ini dilakukan dengan menggunakan teknik purposive sampling, dimana purposive sampling merupakan suatu cara pengambilan sampel dengan tujuan dan pertimbangan tertentu (Hidayat, 2017).

\section{Prosedur}

Penelitian ini merupakan penelitian korelasional yang bertujuan untuk mengetahui hubungan dari dua variabel. Hasil penelitian korelasi hanya mengidentifikasi ada tidaknya hubungan, yang tidak mesti menunjukkan hubungan sebab akibat.

Data, Instrumen dan Teknik Pengumpulan Data Instrumen yang digunakan pada penelitian ini berupa angket self-efficacy yang diadaptasi dari Suprapto, Chang, \& Ku (2017) dengan skala Likert 1 - 4. Skor 4 menyatakan sangat setuju, skor 3 menyatakan setuju, skor 2 menyatakan tidak setuju, dan skor 1 menyatakan sangat tidak setuju. Selain angket, instrumen dalam penelitian ini adalah tes uraian untuk mengukur keterampilan berpiki kritis siswa yang diadaptasi dari Ennis (1985) yang telah disesuaikan dengan Kompetensi Dasar (KD) mata pelajaran kimia pada Standar Isi Kurikulum 2013 edisi revisi 2017. Instrumen keterampilan berpikir terdiri dari 11 soal yang mencakup 11 indikator keterampilan berpikir kritis. Data diolah dengan menggunakan penilaian skala 0-4.

\section{Teknik Analisis Data}


Teknik analisis data yang digunakan adalah analisis kuantitatif, yaitu suatu teknik analisis yang penganalisaannya menggunakan perhitungan, karena data yang didapatkan berhubungan dengan angka. Teknik analisis data yang digunakan pada peneitian ini menggunakan data statistik dengan perhitungan mean, persentase, nilai maksimum, nilai minimum, dan standar deviasi. Hasil penelitian kemudian diinterpretasikan, untuk nilai self-efficacy dikategorikan menurut Sya'ban (2005) sedangkan keterampilan berpikir kritis berpedoman pada penskoran menurut Riduwan (2012)yang disajikan pada Tabel 1 sebagai berikut.

Tabel 1. Kategorisasi Skor Self-efficacy dan Keterampilan Berpikir Kritis

\begin{tabular}{ccl}
\hline Variabel & Interval Skor & \multicolumn{1}{c}{ Kategori } \\
\hline Self- & $>91$ & Sangat Baik \\
efficacy & 70 s.d 91 & Baik \\
& 49 s.d $<70$ & Cukup Baik \\
& $<49$ & Kurang Baik \\
& $81-100$ & Sangat Baik \\
Berpikir & $61-80$ & Baik \\
Kritis & $41-60$ & Cukup \\
& $21-40$ & Kurang \\
& $0-20$ & Sangat Kurang \\
\hline
\end{tabular}

(Sya'ban, 2005; Riduwan, 2012)

Selanjutnya dilakukan uji korelasi dan dilanjutkan uji regresi sederhana untuk mengetahui keterkaitan antara dua variabel tersebut.

\section{HASIL DAN PEMBAHASAN}

Pada penelitian ini digunakan instrumen angket yang diadaptasi dari Suprapto et al., (2017) dengan 28 item pernyataan yang terdiri dari 6 indikator self-efficacy siswa . keenam indikator tersebut adalah science content (SC), high-orderthinking (HOT), laboratory usage (LU), everyday application (EA), science communication (SCM), dan scientific literacy (SL).

Hasil penelitian berupa data statistik untuk mendapatkan gambaran terkait self-efficacy yang dimiliki siswa dan keterampilan berpikir kritis siswa. Tabel 2 menjelaskan gambaran self-efficacy dan keterampilan berpikir kritis siswa secara keseluruhan.

Tabel 2. Gambaran Umum Self-efficacy dan Keterampilan Bepikir Kritis Siswa

Self-efficacy Berpikir Kritis

\begin{tabular}{ccc} 
Mean & 74,64 & 64,13 \\
$\%$ & $66,64 \%$ & $64,13 \%$ \\
Maks & 96 & 86 \\
Min & 55 & 43 \\
SD & 8,681 & 8,139 \\
Jumlah Data & 117 & 117 \\
\hline
\end{tabular}

Standar deviasi data keterampilan berpikir kritis siswa sebesar 8,139 , sapat dikatakan varian data keterampilan berpikir kritis siswa bersifat homogen dibanding self-efficacy siswa. Artinya keterampilan berpikir kritis yang dimiliki siswa hampir sama atau merata. Berbeda dengan selfefficacy siswa, varian data bersifat heterogen ( $\mathrm{SD}=$ 8,681). Artinya keyakinan siswa terhadap kemampuannya dengan siswa yang lain berbeda satu sama lain. Untuk interpretasi skor self-efficacy dijadikan pada Tabel 3.

Tabel 3. Interpretasi Skor Rata-rata self-efficacy

\begin{tabular}{ccc}
\hline $\begin{array}{c}\text { Interval Skor } \\
\text { Ideal }\end{array}$ & $\begin{array}{c}\text { Jumlah } \\
\text { Responden }\end{array}$ & Kategori \\
\hline$>91$ & 1 & Sangat Baik \\
70 s.d 91 & 40 & Baik \\
49 s.d $<70$ & 22 & Cukup Baik \\
$<49$ & 0 & Kurang Baik \\
\hline
\end{tabular}

Berdasarkan hasil perhitungan diketahui bahwa mayoritas tingkatan self-efficacy siswa berada pada kategori baik yaitu sebesar 74,64 dengan persentase ketercapaian sebesar $66,64 \%$. Artinya tingkat keyakinan siswa terhadap kemampuannya sebesar $66,64 \%$. Hasil kategorisasi data yang telah dilakukan menunjukkan tingkat selfefficacy yang dimiliki siswa berada pada kategori baik. Sundari et al., (2016) berpendapat bahwa selfefficacy yang dimiliki siswa sekolah menengah atas berada pada kategori sedang.

Self-efficacy dan berpikir kritis memiliki hubungan yang signifikan dan merupakan salah satu aspek yang mempengaruhi berpikir kritis (Ghanizadeh \& Mirzaee, 2012). Sejalan dengan itu, Gurcay \& Ferah (2018) dalam penelitiannya juga mengatakan terdapat hubungan dalam kategori sedang antara self-efficacy dengan keterampilan berpikir kritis siswa. Artinya, dapat dikatakan bahwa apabila self-efficacy siswa baik maka siswa tersebut juga mampu mengembangkan pemikirannya ke arah pemikiran kritis. Berdasarkan hasil penelitian, nilai rata-rata self- 
efficacy berada pada kategori sedang dan nilai ratarata keterampilan berpikir kritis juga berada pada kategori baik, hal ini mendukung teori bahwa terdapat hubungan yang positf antara kedua variabel tersebut. Hubungan antara self-efficacy dan berpikir kritis mengindikasikan bahwa siswa secara individu yang mempunyai keyakinan tinggi terhadap kemampuannya untuk mencapai kesuksesan dalam mengerjakan tugas juga lebih baik sebagai pemikir kritis. Kepercayaan diri untuk berhasil dalam pelajaran akan meningkatkan keyakinan siswa dalam mengasah kemampuan mereka. Self-efficacy menimbulkan siswa menjadi lebih aktif untuk bertanya, mengkritik, dan mempunyai berbagai cara alternatif untuk dapat memproses pengetahuan saat pembelajaran (Phan, 2009). Siswa yang memiliki keyakinan self-efficacy yang tinggi di kelas akan lebih mampu untuk memahami, membedah dan mengkritik pengetahuan yang diberikan secara pada tingkat yang lebih mendalam dibanding siswa yang cenderung memiliki tingkat keyakinan self-efficacy yang rendah.

Instumen yang mengukur kemampuan berpikir kritis siswa digunakan instrumen tes uraian yang terdiri dari 11 soal yang mencakup 11 indikator keterampilan berpikir kritis dari Ennis (1985). Adapun hasil interpretasi nilai rata-rata keterampilan berpikir kritis siswa disajikan pada Tabel 4.

Tabel 4. Interpretasi Nilai Rata-rata Keterampilan Berpikir Kritis

\begin{tabular}{ccc}
\hline Interval Skor & $\begin{array}{c}\text { Jumlah } \\
\text { Responden }\end{array}$ & Kategori \\
\hline $81-100$ & 1 & Sangat Baik \\
$61-80$ & 45 & Baik \\
$41-60$ & 17 & Cukup \\
$21-40$ & 0 & Kurang \\
$0-20$ & 0 & Sangat Kurang \\
\hline
\end{tabular}

Berpikir kritis merupakan salah satu keterampilan yang wajib dikuasai siswa pada pembelajaran di abad ke 21 ini. berpikir kritis merupakan hasil penalaran atau pemecahan suatu masalah.

Berdasarkan hasil perhitungan diketahui bahwa mayoritas siswa memiliki keterampilan berpikir kritis yang baik. Nilai rata-rata keterampilan berpikir kritis siswa diketahui sebesar

64,13 dengan persentase ketercapaian sebesar 64,13\%. Artinya, keterampilan berpikir kritis siswa dalam ilmu kimia dikategorikan baik. Siswa yang memiliki keterampilan berpikir kritis yang baik akan menyelesaikan sebuah masalah dengan cara pola pikir analitis. Seseorang keterampilan berpikir kritis yang tinggi dapat dikatakan bahwa siswa tersebut mampu merancang langkah-langkah yang tepat yang akan ditempuh untuk mencapai tujuan tertentu, membuat kesimpulan yang akurat dan membuat keputusan yang benar (Gurcay \& Ferah, 2018).

Angket terdiri dari 6 indikator self-efficacy. Self-efficacy pada science content berkaitan dengan keyakinan siswa dalam kemampuan mereka menggunakan kognitif dasar seperti konsep, hukum dasar, dan teori-teori. Self-efficacy pada high-orderthinking berkaitan dengan penilaian kepercayaan terhadap kemampuannya untuk memanfaatkan keterampilan kognitif tingkat tinggi diantaranya pemecahan masalah, berpikir kritis, atau penyelidikan ilmiah. Self-efficacy pada laboratory usage berkaitan dengan mengukur kepercayaan siswa tentang kemampuan mereka dalam melakukan eksperimen di laboratorium. Selfefficacy pada everyday application berkaitan dengan kepercayaan terhadap kemampuannya dalam mengimplementasikan konsep kimia dalam kehidupan sehari-hari. Pada science communication berkaitan dengan kemampuan siswa dalam berkomunikasi atau berdiskusi. Pada scientific literacy berikaitan dengan kemampuan untuk menganalisis dan menafsirkan serta melaporkan hasil kegiatan di laboratorium.

Gambaran self-efficacy siswa untuk setiap indikator disajikan pada Gambar 1.

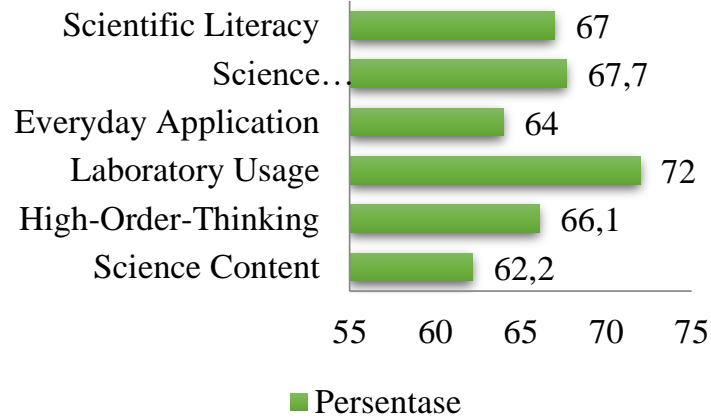


Gambar 1. Gambaran Self-Efficacy Siswa Untuk Setiap Indikator

Persentase ketercapaian self-efficacy diperoleh dari nilai rata-rata dari masing-masing aspek. Persentase ketercapaian tertinggi terdapat pada indikator laboratory usage sebesar $72 \%$ sedangkan persentase ketercapaian terendah terdapat pada indikator science content sebesar $62,2 \%$. Hal ini menandakan siswa cenderung lebih percaya diri dan yakin terhadap kemampuannya dalam kegiatan laboratorium. Menurut Suprapto et al., (2017) tingginya kepercayaan diri peserta didik dalam penggunaan laboratorium dikarenakan kegiatan di laboratorium seperti menyiapkan alat dan bahan untuk percobaan, langkah-langkah percobaan, mengumpulkan data selama kegiatan percobaan selama di laboratorium memiliki pola yang sama untuk setiap materi. Sehingga peserta didik merasa yakin mampu dan berhasil dalam kegiatan di laboratorium.

Berbanding terbalik dengan indikator laboratory usage, indikator science content memiliki persentase ketercapaian terkecil dibandingkan dengan indikator-indikator yang lain. Sehingga dapat dikatakan bahwa masih ditemukan siswa yang masih kurang percaya diri terhadap kemampuannya dalam hal kimia.

Keberagaman tingkat self-efficacy dalam tiap aspek disebabkan oleh beberapa faktor. Bandura (1977) mengatakan bahwa faktor-faktor tersebut dapat berupa pengalaman pribadi siswa, pengalaman orang lain atau teman sebaya, persuasi verbal dan kondisi psikologis siswa. Lemahnya keyakinan diri siswa dalam literasi sains salah satunya dipengaruhi oleh kurangnya pengalaman siswa dalam hal literasi sains. Hasil PISA 2015 menunjukkan bahwa Indonesia dalam kaitannya dengan literasi sains masih tertinggal jauh dibanding negara-negara yang lain yakni urutan ke 63 dari 71 negara. Hal ini menandakan, kegiatan pembelajaran saat ini masih perlu peningkatan dalam kaitannya dengan literasi sains. Metode pembelajaran turut andil dalam hal ini.

Peranan keterampilan berpikir kritis dalam perkembangan self-efficacy cukup besar, karena individu yang intelegensinya tinggi akan lebih mampu mengingat dan menganalisis konsepkonsep kimia yang pernah dialami, sehingga kesimpulan yang dibuat akan lebih tepat. Cheung (2015) berpendapat bahwa siswa yang memiliki tingkat kepercayaan diri yang tinggi terhadap kemampuannya akan lebih mampu mengembangkan pemikirannya ke arah pemikiran kritis. Self-efficacy yang dimiliki siswa/i dalam penelitian inia berada pada kategori baik. Sehingga dapat dikatakan bahwa siswa/i tersebut sudah dapat mengembangkan pemikirannya ke arah pemikiran kritis dengan baik.

Masing-masing indikator self-efficacy memberikan kontribusi yang berbeda-beda untuk keterampilan berpikir kritis. Penentuan sejauh mana nilai self-efficacy siswa mempengaruhi nilai berpikir kritis siswa disajikan dalam Gambar 2 .

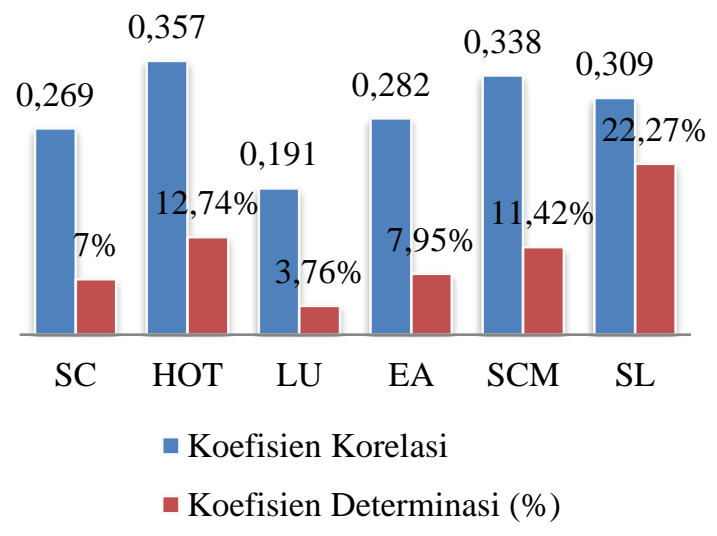

Gambar 2. Kontribusi Self-efficacy dengan Keterampilan Berpikir Kritis

Dapat diketahui bahwa indikator high-orderthinking memiliki nilai koefisien korelasi yang paling tinggi dibandingkan dengan indikator yang lain yaitu sebesar 0,357 dengan kontribusi terhadap self-efficacy sebesar $12,74 \%$. Sedangkan indikator laboratory usage merupakan indikator yang paling lemah korelasinya yaitu sebesar 0,191 dengan kontribusi sebesar 3,76\%. Hal ini dapat dikatakan bahwa, kegiatan di laboratorium tidak secara langsung dapat meningkatkan keterampilan berpikir kritis siswa walaupun kegiatan di laboatorium relatif sama pada setiap subjek di mata pelajaran kimia.

Berdasarkan hasil tersebut juga diketahui bahwa siswa yang merasa yakin mampu 
menggunakan pemikiran kritisnya pada pembelajaran kimia akan mampu memecahkan permasalahan kimia secara sistematis dan logis.

Kimia merupakan salah satu mata pelajaran yang wajib dikuasai pada pembelajaran di abad ke 21 (Redhana, 2019). Karenanya, sudah selayaknya pembelajaran kimia diarahkan pada keterampilan berpikir kritis yang merupakan salah satu keterampilan yang wajib dikuasai pada abad ke 21 . Selain itu, self-efficacy pun perlu dikembangkan guna membantu peningkatan keterampilan berpikir kritis siswa. Apabila siswa merasa percaya diri akan kemampuannya, tentunya siswa akan merasa lebih leluasa untuk mengembangkan pemikirannya dan mengemukakan hasil penalarannya serta mampu menerapkan apa yang didapat saat pembelajaran.

Wilson \& Narayan (2016) menyebutkan bahwa penerapan apa yang individu ketahui dan keterampilan yang dimiliki dipengaruhi oleh selfefficacy. Oleh sebab itu, penting untuk mengetahui peran dari self-efficacy itu sendiri. Banyak pendapat yang menyatakan bahwa self-effcacy memiliki peran sebagai prediktor dan mediator terhadap suatu pencapaian. Wilson \& Narayan (2016) menambahkan, untuk setiap tugas, peserta didik dengan self efficacy yang lebih tinggi memiliki kinerja tugas yang lebih baik.

Pengembangan keterampilan berpikir kritis tidak bisa dilakukan tanpa adanya upaya yang terencana dan sistematis, melainkan harus dilakukan secraa sengaja dengan membuat rencana yang tepat sasaran seperti membuat masalah terbuka dan kurang terstruktur untuk memulai pembelajaran, menugaskan siswa memeahkan masalah secara sistematis, serta mengarahkan siswa mencari informasi secara mandiri terkait permasalahan yang diberikan (Redhana, 2019). Selain mampu meningkatkan keterampilan berpikir kritis, sistem pembelajaran tersebut juga mampu meningkatkan kepercayaan diri siswa terkait konsep (Self-efficacy) yang didapatkan siswa melalui penalaran yang sistematis.

\section{SIMPULAN}

Berdasarkan hasil penelitian, analisis data, dan pembahasan yang telah diuraikan sebelumnya, maka dapat disimpulkan bahwa:
1. Self-efficacy dan Keterampilan Berpikir Kritis Siswa berada pada kategori baik dengan nilai sebesar 74,64 dengan persentase ketercapaian sebesar $66,64 \%$. Artinya tingkat keyakinan siswa terhadap kemampuannya sebesar $65,74 \%$. Sedangkan untuk keterampilan berpikir kritis siswa sebesar 64,13 dengan persentase ketercapaian sebesar $64,13 \%$.

2. Indikator-indikator self-efficacy antara lain science content, high-order-thinking, laboratory usage, everyday application, science communication, dan scientific literacy memberikan hubungan yang positif dengan keterampilan berpikir kritis siswa. High-orderthinking memberikan kontribusi paling besar terhadap keterampilan berpikir kritis siswa pembelajaran kimia yaitu sebesar $12,74 \%$, sedangkan laboratory usage memberikan kontribusi paling sedikit yaitu sebesar 3,67\%.

\section{UCAPAN TERIMA KASIH}

Terima kasih peneliti haturkan kepada Program Studi Pendidikan Kimia UIN Syarif Hidayatullah Jakarta yang turut membatu mewujudkan penelitian ini, juga kepada semua pihak yang telah membantu dalam penelitian ini yang tidak bisa disebutkan satu persatu.

\section{DAFTAR PUSTAKA}

Bandura, A. (1977). Self-efficacy: toward a unifying theory of behavioral change. Psychological Review, 84(2), 191.

Bandura, A. (2010). Self-efficacy. The Corsini Encyclopedia of Psychology, 1-3.

Cheung, D. (2015). The combined effects of classroom teaching and learning strategy use on students' chemistry self-efficacy. Research in Science Education, 45(1), 101-116.

De Bono, E. (2007). Revolusi berpikir. Bandung: Mizan Media Utama.

Ennis, R. H. (1985). A logical basis for measuring critical thinking skills. Educational Leadership, 43(2), 44-48.

Ghanizadeh, A., \& Mirzaee, S. (2012). EFL learners' self-regulation, critical thinking and language achievement. International Journal of Linguistics, 4(3), 451-468. 
Gurcay, D., \& Ferah, H. O. (2018). High School Students' Critical Thinking Related to Their Metacognitive Self-Regulation and Physics Self-Efficacy Beliefs. Journal of Education and Training Studies, 6(4), 125-130.

Hidayat, A. (2017). Penjelasan Teknik Purposive Sampling Lengkap Detail. Retrieved August 28, 2019, from https://www.statistikian.com/2017/06/penjela san-teknik-purposive-sampling.html

Hoffman, B., \& Schraw, G. (2009). The influence of self-efficacy and working memory capacity on problem-solving efficiency. Learning and Individual Differences, 19(1), 91-100.

Hohmann, J. W., \& Grillo, M. C. (2014). Using critical thinking rubrics to increase academic performance. Journal of College Reading and Learning, 45(1), 35-51.

Mabruroh, F., \& Suhandi, A. (2017). Construction of critical thinking skills test instrument related the concept on sound wave. In Journal of Physics: Conference Series (Vol. 812, p. 12056). IOP Publishing.

Pajares, F. (2002). Self-efficacy Beliefs in Academic Setting: Review of Educational Research. Florida: Educational Research Council Research Bulletin.

Phan, H. P. (2009). Relations between goals, selfefficacy, critical thinking and deep processing strategies: a path analysis. Educational Psychology, 29(7), 777-799.

Redhana, I. W. (2019). Mengembangkan Keterampilan Abad Ke-21 dalam Pembelajaran Kimia. Jurnal Inovasi Pendidikan Kimia, 13(1).

Riduwan. (2012). Belajar Mudah Penelitian Untuk Guru-Karyawan dan Peneliti Pemula. Bandung: Alfabeta.
Rusman. (2013). Belajar dan Pembelajaran Berbasis Komputer: Mengembangkan Profesionalisme Abad 21. Bandung: Alfabeta.

Santrock, J. W., \& Santrock, J. W. (2007). Psikologi Pendidikan edisi kedua. Kencana Prenada Media Group.

Sukartono. (2019). Revolusi Industri 4.0 dan Dampaknya Terhadap Pendidikan di Indonesia. Surakarta.

Sundari, P. D., Parno, \& Kusairi, S. (2016). Hubungan Antara Efikasi-diri dan Kemampuan Berpikir Kritis Siswa. In Semnas Pendidikan IPA Pascasarjana UM (pp. 405415). Malang. Retrieved from http://pasca.um.ac.id/wpcontent/uploads/2017/02/Putri-Dwi-405415.pdf

Suprapto, N., Chang, T.-S., \& Ku, C.-H. (2017). Conception of learning physics and selfefficacy among Indonesian university students. Journal of Baltic Science Education, 16(1), 7-19.

Sutarno, S., Setiawan, A., Suhandi, A., Kaniawati, I., \& Hamdani, D. (2018). Model Higher Order Thinking Virtual Laboratory: Model Praktikum Fisika Berbasis Keterampilan Berpikir Kritis dan Pemecahan Masalah Secara Kreatif. Jurnal Pendidikan Eksakta, 3(5).

Sya ‘ban, A. (2005). Teknik Analisis Data Penelitian Aplikasi program SPSS dan Teknik Menghitungnya, 1-71. Universitas Muhammadiyah Prof. Dr. Hamka.

Wilson, K., \& Narayan, A. (2016). Relationships among individual task self-efficacy, selfregulated learning strategy use and academic performance in a computer-supported collaborative learning environment. Educational Psychology, 36(2), 236-253. 